\title{
SEDIMENT CARBON STOCK OF WEST KALIMANTAN MANGROVE FORESTS
}

\author{
Tia Nuraya ${ }^{1 *}$, Alan Frendy Koropitan ${ }^{1}$ and A'an Johan Wahyudi ${ }^{2}$ \\ ${ }^{1}$ Faculty of Fisheries and Marine Sciences, Bogor Agricultural University (IPB). Bogor, Indonesia. \\ ${ }^{2}$ Research Center for Oceanography, Indonesian Institute of Sciences (LIPI). Jakarta, Indonesia. \\ *Correspondence author:<tia_nuraya@yahoo.com>
}

Received: March $2019 \quad$ Accepted: June 2019

\begin{abstract}
We investigate variation in sediment carbon stock at Mempawah and Bakau Besar in West Kalimantan by analyzing organic carbon content from sediment samples taken within $20 \mathrm{~cm}$ depth. Our results show that organic carbon stock of sediments in Bakau Besar is generally higher than in Mempawah that may be due to riverine input of organic carbon into the mangrove forests. The riverine input of organic carbon is influenced tides, in which we find that organic carbon loads are higher during high tide compared to low tide. In particular, we find high organic carbon contents at a station in Mempawah (Station 3; $6.46 \pm 0.23$ tons C/ha) and another station in Bakau Besar (Station $2 ; 14.93 \pm 1.43$ tons $\mathrm{C} / \mathrm{ha}$ ). These two stations have mangrove density of 13,519 individuals/ha and 9,928 individuals/ha, respectively. We conclude that high organic carbon is influenced by riverine input as well as a high density of mangrove and the dominant type of mangrove vegetation at the sites.
\end{abstract}

Keywords: Mangrove ecosystem, organic carbon, riverine input, West Kalimantan, Indonesia.

\section{INTRODUCTION}

Mangrove ecosystems play an important role in sequestering carbon (Twilley et al., 1992; Alongi, 2012; Mudiyarso et al., 2015), thus mitigating anthropogenic climate change since the industrial revolution (Hofmann et al., 2009). Mangroves absorb carbon dioxide during the photosynthesis process that subsequently accumulates as biomass above or below, in sediments and as dead trees (Mcleod et al., 2010). The process of absorbing and exporting carbon varies considerably in mangrove ecosystems, depending on forest density, tides, the abundance of sediments, and anthropogenic impacts (Kristensen et al., 2008). For example, mangrove roots can trap more fine sediments from river flows and tidal currents (Tue et al., 2012). Moreover, the organic carbon in sediments also increases with the age of the sediment (Chen et al., 2018). In all, the capability of mangrove to absorb carbon may help to reach the goal of the Paris Agreement to maintain a global temperature increase below $2^{\circ} \mathrm{C}$ (Figueres et al., 2017).

Indonesia has the largest mangrove area in the world (Giri et al., 2011) with 3.5 million ha of mangrove ecosystems across 257 regencies and cities. In the West Kalimantan Province, Mempawah Regency has a mangrove ecosystem of 739.31 ha. Mangrove forests in Mempawah are passed through by the Kapuas River, the longest river in Indonesia, that brings in organic matters into mangrove forests.

This study aims to investigate the variation of sediment organic carbon under different environmental settings in Mempawah Regency. Despite having a vast mangrove area, currently, there is no systematic study of carbon dynamics in the area that could have microhabitats biogeochemical carbon cycles. Results from this 
study could enhance our knowledge of the role of mangrove ecosystems to sequester carbon. Further, the knowledge could benefit the local governments for mangrove forest management and encourage public awareness of mangrove conservation.

\section{MATERIALS AND METHODS}

\section{Study Sites}

Field sampling was conducted on September 2018 at two locations in Mempawah Regency $\left(0^{\circ} 44^{\prime} \mathrm{N}-0^{\circ} 00.4^{\prime} \mathrm{S}, 108^{\circ} 24^{\prime}-109^{\circ} 21.5^{\prime} \mathrm{E}\right)$, which are Mempawah and Bakau Besar (Figure 1). The Mempawah site has three sampling stations, and Bakau Besar has four sampling stations. Geographically, Mempawah Regency is bordered by the Natuna Sea in the west, the Landak Regency in the east, the Bengkayang Regency in the north and the Kubu Raya Regency in the south.

Mempawah and Bakau Besar have different environmental settings. Mangrove forests in Mempawah are connected by a canal. As for the Bakau Besar, there is a river connected to the Kapuas River, that may become one of the sources of the organic material input to mangrove forests. The area of mangrove that has become a conservation area in Mempawah and Bakau Besar is 4 ha and 5 ha, respectively.

Sample analysis was carried out at Biogeochemical Laboratory and Geological Laboratory at Research Center for OceanographyLIPI in Ancol and Plant Ecology Laboratory at Research Center for Biology-LIPI in Cibinong in October 2018.

\section{Water Sampling \& Hydrological Data}

Water samples $(\sim 1000 \mathrm{ml})$ were taken during high and low tide to analyze total suspended solids (TSS) and total organic carbon (Banse et al., 1963; Strickland and Parson, 1968). Water samples were filtered using a vacuum pump and $\mathrm{GF} / \mathrm{F} \varnothing 47 \mathrm{~mm}$ filter. The filtrate obtained from the filter was wrapped using aluminum foil, packed using plastic clips, and then put into a cooler box at $4^{\circ} \mathrm{C}$ during transport to the laboratory.

We collected data on tide using tidal forecasting data from the Bali tides application on September 30 (high tide at 5:30 pm and low tide at 11:30 am) and October 1 (high tide at 8:00 am and low tide at 1:30 pm), current using the

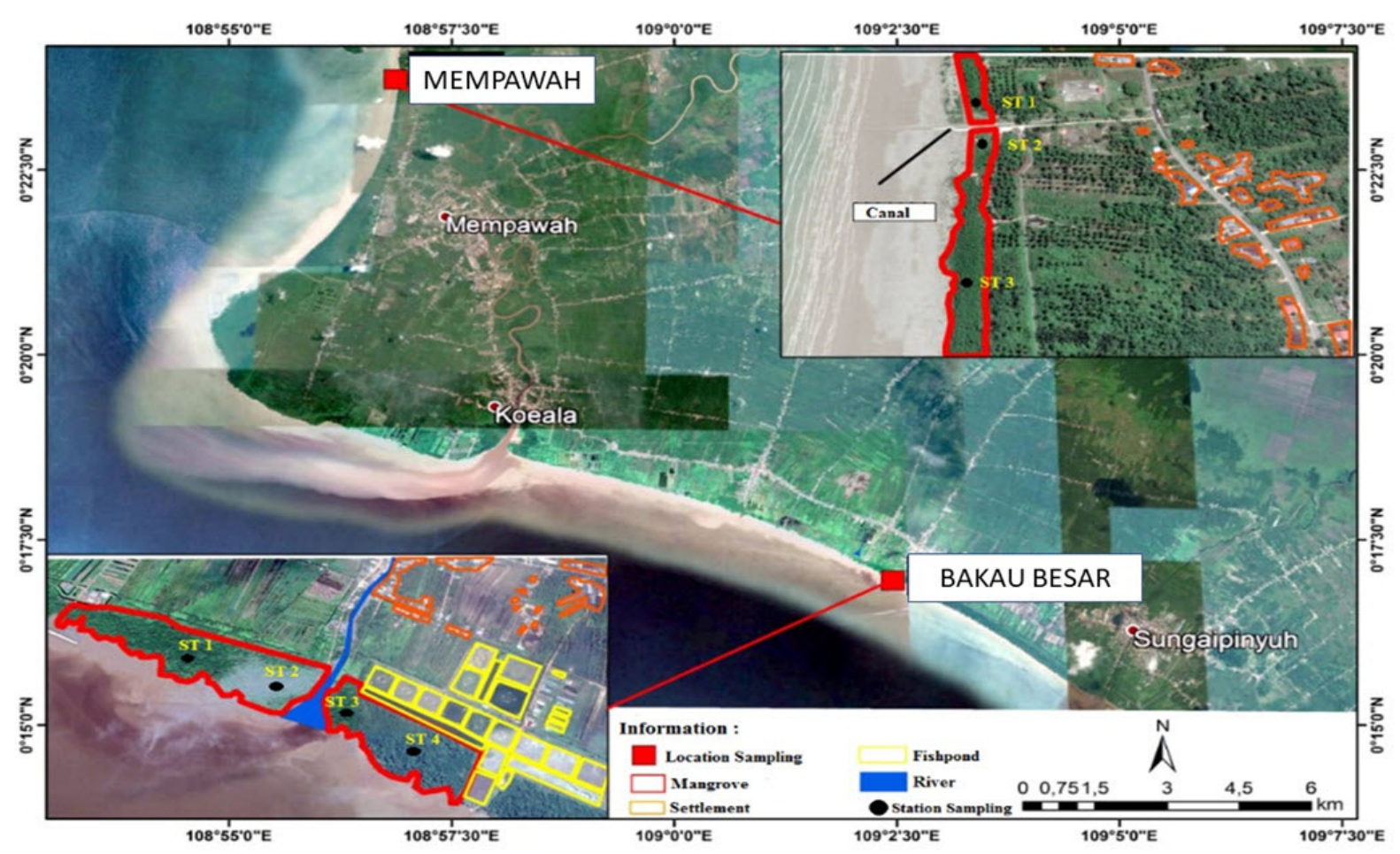

Figure 1. Study sites showing sampling stations in Mempawah and Bakau Besar. 
current kite method, and calculated discharge (Q) of the river or canal following:

$$
Q=\text { current } x \text { cross sectional area }
$$

where current is in $\mathrm{m} / \mathrm{s}$, and cross-sectional area $\left(\mathrm{m}^{2}\right)$ is the product of depth (m) and width (m) of the river or canal.

\section{Mangrove Density \& Sediment Sampling}

We measured mangrove density using circular plot transects where measurements were made at a radius of $7 \mathrm{~m}$ and $2 \mathrm{~m}$ with an area of $\mathrm{A}=153.9$ $\mathrm{m}^{2}$ and $\mathrm{A}=12.6 \mathrm{~m}^{2}$. Measurement at the radius of $7 \mathrm{~m}$ was for trees that have the diameter at breast height $(\mathrm{DBH})>5 \mathrm{~cm}$, while the radius 2 $\mathrm{m}$ for trees that have DBH $<5 \mathrm{~cm}$ (Kauffman and Donato, 2012). DBH measurements were carried out on each tree that has a height of more than $130 \mathrm{~cm}$. Mangrove density (individuals/ha) as the following:

$$
\text { density }=\frac{\text { number of trees }}{\text { sample plot area }}
$$

Surface sediment samples were taken within the top $20 \mathrm{~cm}$ using polyvinyl chloride (PVC) pipes in the middle of the transect. The sediment samples were wrapped using aluminum foil and plastic and stored in a cooler box at $4^{\circ} \mathrm{C}$ during transport to the laboratory to minimize microbial activity. Each sediment sample was analyzed for organic carbon and grain size.

\section{Total Suspended Solids and Total Carbon}

We follow the loss on ignition (LOI) method of Helrich (1990) that consists of TSS, total organic matter (TOM), and total organic carbon (TOC) measurements.

For analyzing TSS (mg/L), samples were dried in an oven at $60^{\circ} \mathrm{C}$ for 3 hours, weighted using an analytical balance, and estimated following the equation:

$$
\text { TSS }=(B-A) x \frac{1000}{\text { volume of sample }(\mathrm{mL})} \quad \text { Eq.3 }
$$

where A is the weight of blank glass filter (mg), and $\mathrm{B}$ is the total weight of glass filter and the filtrate (mg).
The dried TSS sample was furnaced at $450^{\circ} \mathrm{C}$ for 4 hours to estimate TOM following the equation:

$$
\text { TOM }=\frac{[(b-a)-(c-a)]}{b-a} \times 100 \%
$$

where

$\mathrm{a}=$ weight of a cup

$\mathrm{b}=$ weight of a cup + sample

$c=$ weight of a cup + dust/remain.

TOC was calculated following the equation:

$$
\text { TOC }=\frac{\text { TOM }}{1.724} \quad \text { Eq. } 5
$$

where 1.724 is the constant value of organic matter total carbon.

The calculation of a total load of organic carbon $(\mathrm{g} / \mathrm{s})$ is:

$$
\text { load }=\text { concentration } x \text { debit Eq. } 6
$$

where concentration is in $\mathrm{g} / \mathrm{ml}$ and debit in $\mathrm{m}^{3} / \mathrm{s}$.

\section{Sediment Organic Carbon}

Sediment samples were analyzed for carbon and nitrogen concentrations via the combustion method using a CHN analyzer (Kristensen, 1987). Bulk density (BD, in $\mathrm{g} / \mathrm{m}^{3}$ ) was calculated from dried samples (Kauffman and Donato, 2012):

$$
\mathrm{BD}=\frac{\text { dry weight of sample }}{\text { volume of sample }}
$$

We calculate the $\mathrm{C} / \mathrm{N}$ ratio to understand sources of organic carbon contained in sediments. Previous works showed that the $\mathrm{C} / \mathrm{N}$ ratio of less than 8 indicates that the source of organic material comes from the sea, while the $\mathrm{C} / \mathrm{N}$ ratio of more of 12 indicates the riverine source of organic matter (Meyers, 2003; Xue et al., 2009). The calculation of sediment TOC followed the equation by Poeplau et al. (2017):

$$
\text { TOC }=B D \times \text { depth } x \% C
$$

Eq. 8

\section{Grain Size and Sediment Type}

For grain size (sand, silt, and clay) analysis, sediment samples were dried in an oven at 
$100^{\circ} \mathrm{C}$, sieved using multi-level filters $(2,0.5$, 0.125 and $0.063 \mathrm{~mm}$ ), and weighted. For smaller grain sizes, we used the pipette method where samples measuring $0.063 \mathrm{~mm}$ were put into a $1 \mathrm{~L}$ measuring cup, stirred until homogeneous, then the pipetting process was carried out with the specified pipette distance and time (McIntyre and Holme, 1984). Organic matter was previously removed using $\mathrm{H}_{2} \mathrm{O}_{2}$. The results are reported using the Wentworth's classification.

\section{RESULTS}

\section{Organic Carbon in Sediment and Water}

We find higher organic carbon stock in sediments from Bakau Besar compared to Mempawah (Figure 2). In Mempawah, the highest organic carbon stock is at station 3 with a value of $6.46 \pm 0.23$ tons $\mathrm{C} / \mathrm{ha}$, followed by station 2 $(5.65 \pm 0.29$ tons $\mathrm{C} / \mathrm{ha})$ and station $1(5.64 \pm 0.45$ tons $\mathrm{C} / \mathrm{ha}$ ). The highest organic carbon stock in Bakau Besar location occurs at station 2 (14.93 \pm 1.43 tons $\mathrm{C} / \mathrm{ha}$ ) and is the lowest at station 3 ( $7.61 \pm 0.20$ tons $\mathrm{C} / \mathrm{ha}$ ), whereas stations 1 and 4 have organic carbon stocks at $11.77 \pm 3.08$ tons $\mathrm{C} /$ ha and $11.95 \pm 0.09$ tons $\mathrm{C} / \mathrm{ha}$, respectively. The carbon stock values correspond to the $\mathrm{C} / \mathrm{N}$ ratios (Figure 3) with a maximum $\mathrm{C} / \mathrm{N}$ ratio of 13.685 at station 2 .

The total organic carbon load is higher in the river than the canal, with the higher load during high tide (Figure 4).

\section{Sediment Types}

Mempawah sediments consist of clay, silt, and very fine sand, whereas Bakau Besar sediments consist of clay, silt, very fine sand, fine sand, and medium sand (Figure 5). Silt (grain size of 0.004$0.063 \mathrm{~mm}$ ) is the dominant sediment type in both Mempawah and Bakau Besar, followed by clay. The percentage of silt at Mempawah is about $70 \%$ in all stations, followed by clay at about $20 \%$. In Bakau Besar, station 4 has the highest percentage of silt $(71 \%)$ while the percentages are $64 \%$ (station 1), 65\% (station, 2), and 58\% (station 3 ). Whereas clay has an average percentage of around $25 \%$ at all stations in Bakau Besar. Fine sediment is about $3 \%$ in Bakau Besar.
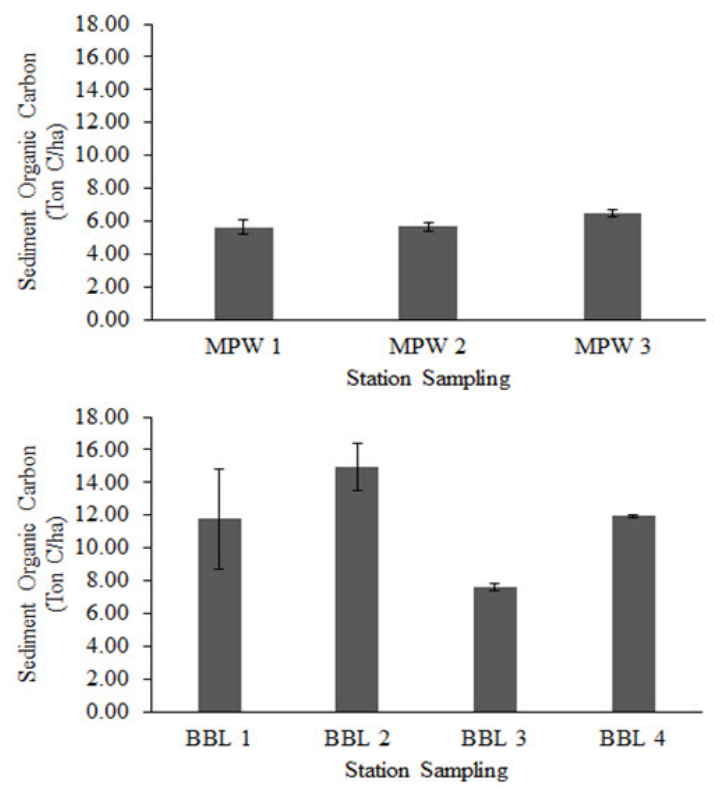

Figure 2. Organic carbon stock of Mempawah (MPW) and Bakau Besar (BBL) sediments.

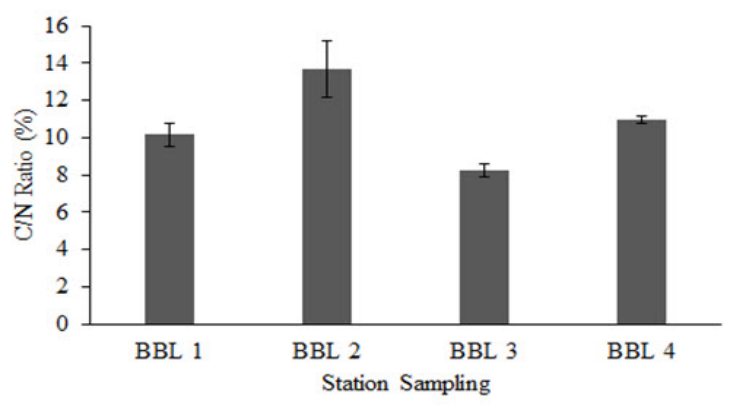

Figure 3. $\mathrm{C} / \mathrm{N}$ ratio of Bakau Besar sediments.

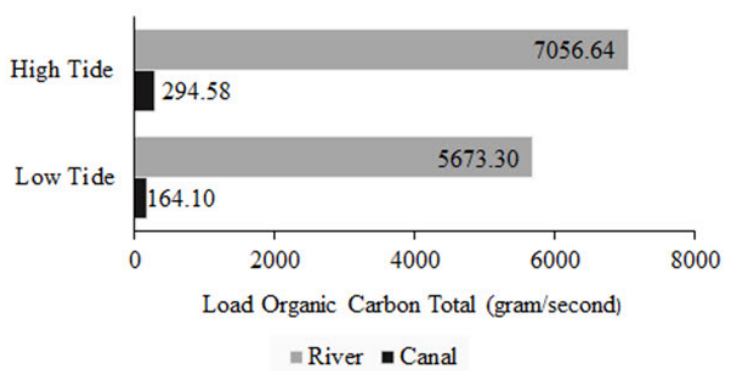

Figure 4. Load of total organic carbon during high and low tide in river and canal.

\section{Mangrove Community Structure}

The types of mangrove present in the study sites, density, and DBH are shown in Table 1. 


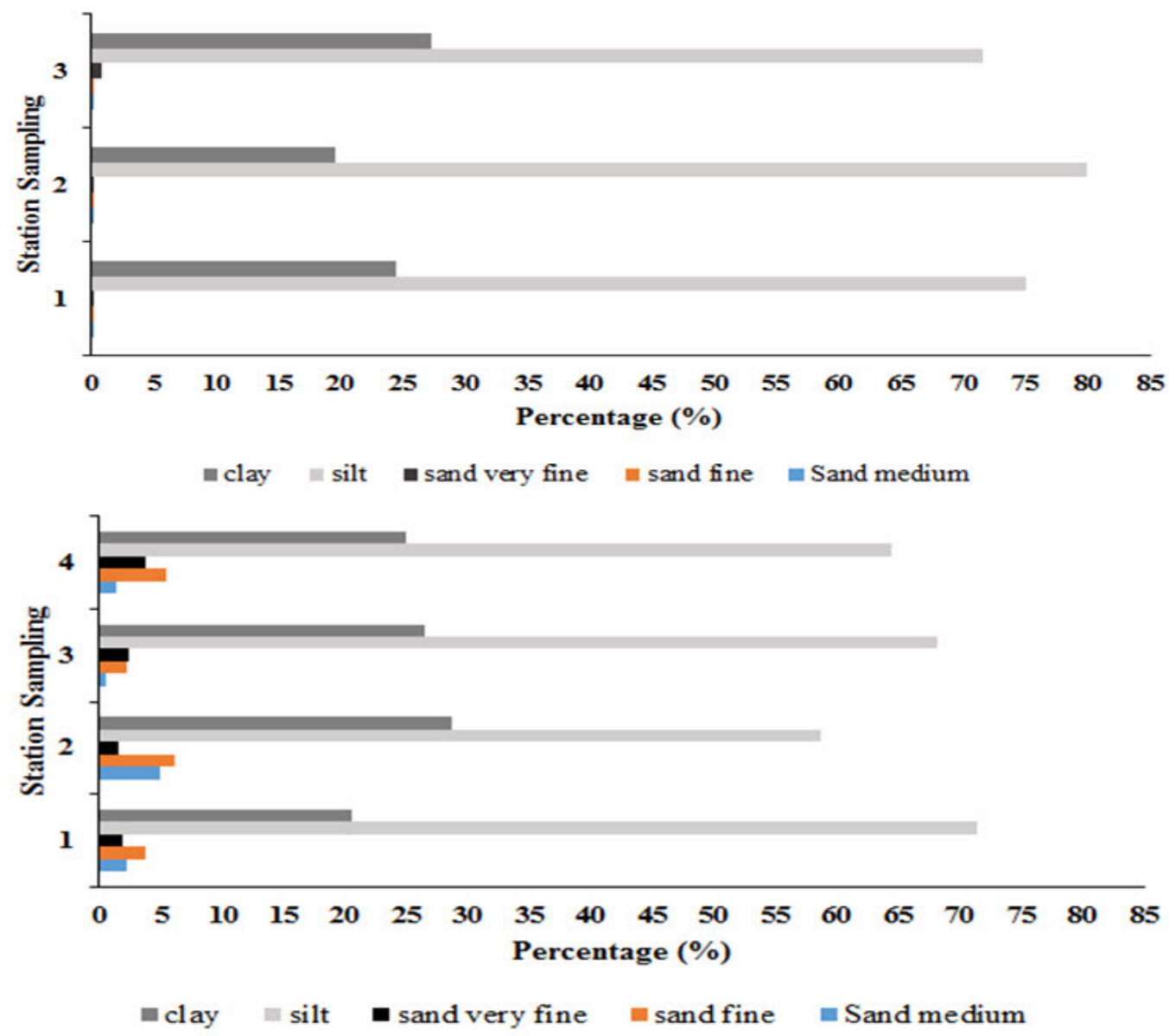

Figure 5. Percentage of grain size in Mempawah (top) and Bakau Besar (bottom).

Table 1. Mangrove species based on density and DBH (individuals/ha).

\begin{tabular}{lccccccc}
\hline Tree Structure & \multicolumn{3}{c}{ MPW } & \multicolumn{7}{c}{ Study Sites } \\
\hline Mangrove Species & ST 1 & ST 2 & ST 3 & ST 1 & ST 2 & ST 3 & ST 4 \\
Avicennia aureum & 9,538 & - & 796 & - & - & - & - \\
Avicennia marina & - & 10,239 & 7,149 & - & 130 & - & - \\
Rhizophora stylosa & - & 796 & 5,573 & 796 & - & 3,981 & 65 \\
Rrhizophora Mucronata & - & - & - & 861 & - & 130 & - \\
Bruguiera cylindrica & - & - & - & 650 & 9733 & - & - \\
Excoecaria agallacha & - & - & - & - & 65 & 1,592 & - \\
Avicennia lanata & - & - & - & 130 & - & 1,121 & - \\
Xylocarpus granium & - & - & - & - & - & 796 & 6,548 \\
& & & & & & & \\
Total Density (individual/ha) & 9,538 & 10,935 & 13,519 & 2,437 & 9,928 & 7,621 & 6,613 \\
& & & & & & & \\
DBH & & & & & & & \\
$<5 \mathrm{~cm}$ & 8,758 & 10,350 & 12,739 & 1,592 & 8,758 & 7,166 & 5,573 \\
$>5 \mathrm{~cm}$ & 780 & 585 & 780 & 845 & 1,170 & 455 & 1,040 \\
\hline
\end{tabular}


Avicennia species dominate across sampling sites in Mempawah, while Bakau Besar is dominated by Bruguiera at stations 1 and 2, Rhizophora stylosa at station 3, and Xylocarpus at station 4 .

The total density of mangrove is higher in Mempawah ranging from 9,538- 13,519 individuals/ha compared to Bakau Besar with a range of 2,437-9,928 individuals/ha.

The DBH data how that there are more small trees $(\mathrm{DBH}<5 \mathrm{~cm})$ in Mempawah compared to Bakau Besar.

\section{Tides and Discharge Measurements}

Hydrographic data (tides and discharge) are shown in Table 2.

The study site has diurnal tidal cycle) with maximum high tide and minimum low tide occur once a day. Tidal height during high tide was 0.9 $\mathrm{m}$ (September 30, 2018) and $1.2 \mathrm{~m}$ (October 1, 2018), and correspondingly were $0.6 \mathrm{~m}$ and 0.8 $\mathrm{m}$ during low tide.

River and canal discharges measured during high and low tides show that the highest discharge in Mempawah's canal occurs during low tide and in Bakau Besar's river during high tide condition.

Table 2. Tide and discharge data.

\begin{tabular}{lllll}
\hline \multirow{2}{*}{ Location } & \multicolumn{2}{l}{ Tide $(\mathbf{m})$} & \multicolumn{2}{l}{$\begin{array}{l}\text { Discharge } \\
\left(\mathbf{m}^{3} / \mathbf{s}\right)\end{array}$} \\
& $\begin{array}{l}\text { High } \\
\text { Tide }\end{array}$ & $\begin{array}{l}\text { Low } \\
\text { Tide }\end{array}$ & $\begin{array}{l}\text { High } \\
\text { Tide }\end{array}$ & $\begin{array}{l}\text { Low } \\
\text { Tide }\end{array}$ \\
\hline Mempawah & 0.9 & 0.6 & 0.162 & 0.222 \\
Bakau Besar & 1.2 & 0.8 & 2.116 & 2.110 \\
\hline
\end{tabular}

\section{DISCUSSION}

Higher organic carbon in Bakau Besar compared to Mempawah could be due to river input, consistent with $\mathrm{C} / \mathrm{N}$ ratios higher than 12. The value total organic carbon load is also higher in riverine setting compared to the canal in Mempawah during both high and low tide conditions. The total flow of organic carbon comes from many sources, one of which is input from rivers that contributes extensive and developing mangrove forests (Woodroffe, 1992). Globally, about $900 \mathrm{Tg}\left(\mathrm{Tg}=1 \times 10^{12} \mathrm{~g}\right)$ of carbon come from various terrestrial sources in which a large portion of organic carbon burial occurs in shallow marine systems (Wang et al., 2012), thus rivers and estuaries play a key role in the global carbon cycle. Bakau Besar also has more large trees and is still in a natural area.

Variation in organic carbon in sediments within each site may relate to specific environmental settings. In Mempawah, high organic carbon at station 3 may be due to proximity to the beach, while lower carbon stocks at stations 1 and 2 may be due to their proximity to the canal where organic carbon enters and exits. Nehren and Wicaksono (2018) suggest that soil carbon stocks are higher with a short distance from the coastline. In Bakau Besar, station 3 is located near the fishpond area. The low level of organic carbon in the fishpond area where the effect of human management and reduced vegetation on mangrove land could cause lower organic carbon. This observation is consistent with Rahmah et al. (2014).

We find an inverse relationship between grain size and organic carbon. Higher clay percentage is found in Mempawah's station 3 and Bakau Besar's station 2 that have the highest carbon stocks within each site. Finer sized particles have higher organic matter content as a result of decomposition processes. Dominant silt and clay found in our study sites are similar to other reported sites (e.g., Hien et al., 2018) that found $\sim 95 \%$ of silt and clay types on the surface of the mangrove sediment. Finer sediments are trapped by mangrove roots, thus vary depending on river and tide currents (Banerjee et al., 2018; George et al., 2018).

Tide and river discharge can affect the values of organic carbon. During high tide, higher carbon load may be due to stronger mixing as seawater enters the river. High tide brings sediments from the sea to be deposited in the river, thus increases suspended material deposits (Burchard et al., 2018). These materials could spread again in the sea during the low tide and reduces the material load in the river. River and canal discharges also could alter the amount of suspended matters of terrestrial origins.

Corresponding to higher carbon stocks, we find higher mangrove density Mempawah's station 3 and Bakau Besar's station 2. Dominant mangrove vegetations such as Avicennia and Bruguiera are also better in storing carbon. 
Avicennia stores more carbon as it has harder stems (Rahman et al., 2017). Bruguiera has a knee root type capable of growing on clay substrates. Similarly, Afiati et al. (2014) show that Avicennia and Bruguiera species in Tanjung Lesung, Banten, absorb more organic carbon in the sediments compared to other types.

We find more small trees (DBH $<5 \mathrm{~cm}$ ) in Mempawah and Bakau Besar because they are restoration areas, in addition to natural mangroves present in Bakau Besar. DBH values show distribution of mangrove biomass, in which mangrove restoration can increase carbon stocks (Ren et al., 2010; Lovelock et al., 2011; Osland et al., 2012; Marchand, 2017) with soil carbon stocks increase with the age of mangroves (Chen et al., 2018). The number of mangrove trees also could increase organic carbon (Retnowati, 1998). Generally, mangrove forests with many trees can store more carbon stocks. Carbon stored in trees in the form of lower biomass and litter accumulates in sediments so that high content of organic matter in the surface layer can also come from mangrove litter that undergoes a decomposition process (Alongi, 2012). Soil organic carbon also increases with the growth of plant biomass (Rozainah et al., 2018; Etemadi et al., 2018).

The results from this study indicate lower sediment organic carbon stock compared to previous studies (Table 3). This could be due to shallower sampling depth $(20 \mathrm{~cm})$ as deeper depths may have higher carbon with the accumulation of organic carbon in the inner layer. However, Rozainnah et al. (2018) found higher carbon stock using similarly $20 \mathrm{~cm}$ of sampling depth in the Delta of the Kelantan that could be due to differences in the conditions of the study site and the input of organic matter originating around Delta Kelantan.

Table 3. The comparison of sedimentary organic carbon stocks.

\begin{tabular}{|lccc|}
\hline Location & $\begin{array}{c}\text { Sampling } \\
\text { depth (cm) }\end{array}$ & $\begin{array}{c}\text { Organic carbon } \\
\text { (tons C/ha) }\end{array}$ & Reference \\
\hline $\begin{array}{l}\text { Mempawah, West Kalimantan } \\
\text { (Indonesia) }\end{array}$ & 20 & $5.92 \pm 0.32$ & This study \\
\hline $\begin{array}{l}\text { Bakau Besar, West Kalimantan } \\
\text { (Indonesia) }\end{array}$ & 20 & $11.57 \pm 1.20$ & This study \\
\hline Banda Aceh (Indonesia) & $15-30$ & 14.82 & Rahmah et al, 2014 \\
\hline $\begin{array}{l}\text { Delta Kelantan (Malaysia) } \\
\text { Kongsi Island (Indonesia) }\end{array}$ & 20 & 24.72 & Rozainah et al, 2018 \\
\hline $\begin{array}{l}\text { Mangrove Forest (Iran) } \\
\text { Cemare Village, West Lombok }\end{array}$ & 100 & $37 \pm 3$ & Kusumaningtyas et al, 2018 \\
\hline $\begin{array}{l}\text { (Indonesia) } \\
\text { Berau, East Kalimantan (Indonesia) }\end{array}$ & 100 & 60 & Etemadi et al, 2018 \\
\hline $\begin{array}{l}\text { Kubu Raya, West Kalimantan } \\
\text { (Indonesia) }\end{array}$ & 136 & $99.92 \pm 14.81$ & Paputungan et al, 2017 \\
\hline
\end{tabular}

\section{CONCLUSION}

We investigate variation in sediment carbon stock at Mempawah and Bakau Besar in West Kalimantan by analyzing organic carbon content from sediment samples. Carbon stocks in Bakau
Besar are higher than Mempawah that may be due to a combination of riverine input, the density of mangrove, and dominant types of mangrove vegetation at the sites. 


\section{ACKNOWLEDGEMENT}

We thank technicians of the Biogeochemistry Laboratory of the Research Center for Oceanography - LIPI for assisting laboratory analyses and the local government of Mempawah Regency for permitting field sampling.

\section{REFERENCES}

Afiati, R. N., Rustam, A., Kepel, T. L., Sudirman, N., Astrid, M., Daulat, A., Mangindaan, P., Salim, H. L., and Hutahaean, A. A. (2014). Carbon stock and mangrove community structure as blue carbon in Tanjung Lesung, Banten. Segara, 2(2), 119-127.

Alongi, D. M. (2012). Carbon sequestration in mangrove forests. Carb. Manag., 3(3), 313322. doi:10.1007/978-1-4020-8343-3_17.

Banerjee, K., Bal, G., and Mitra, A. (2018). How soil texture affects the organic carbon load in the mangrove ecosystem? A case study from Bhitarkanika, Odisha. Environ. Poll., 329341. doi:10.1007/978-981-10-5792-2 27.

Banse, K., Falls C. P., and Hobson, L. A. (1963). A gravimetric method for determining suspended matter in seawater using millipore filter. Deep sea. Res., 10, 639-642. doi:10.1016/00117471(63)90005-6.

Burchard, H., Schuttelaars H. M., and Ralston, D. K. (2018). Sediment trapping in estuaries. Ann. Rev. Mar. Sci., 3, 10, 371-395. doi:10.1146/ annurev-marine-010816-060535.

Chen, G., Gao, M., Pang, B., Chen, S., and Ye, Y. (2018). Top-meter soil organic carbon stocks and sources in restored mangrove forests of different ages. Forest Ecol. Manag., 422, 8794. doi:10.1016/j.foreco.2018.03.044.

Etemadi, H., Smoak, J. M., and Sanders, C. J. (2018). Forest migration and carbon sources to Iranian mangrove soils. J. Arid Environ., 157, 57-65. doi:10.1016/j.jaridenv.2018.06.005.

Figueres, C., Schellnhuber, H. J., Whiteman, G., Rockström, J., Hobley A., and Rahmstorf, S. (2017). Three years to safeguard our climate. Nature, 546, 593-595. doi:10. 1038/546593a.
George, D. A., Largier, J. L., Storlazzi, C. D., Robart, M. J., and Gaylord, B. (2018). Currents, waves and sediment transport around the headland of Pt. Dume, California. Cont. Shelf Res.., 17, 1-54. doi:10.1016/j. csr.2018.10.011.

Giri, C., Ochieng, E., Tieszen, L. L., Zhu, Z., Singh., A., Loveland, T., Masek, T., and Duke, T. (2011). Status and distribution of mangrove forests of the world using earth observation satellite data. Global. Eco. Biogeogr., 20, 154159. doi:10.1111/j.1466-8238.2010.00584.x.

Helrich, K. (1990). Method of analysis of the association of official analytical chemist. Virginia: Arlingto County, (pp. 15).

Hien, H. T., Marchand, C., Aimé, J., and Cuc, N. T. K. (2018). Seasonal variability of $\mathrm{CO}_{2}$ emissions from sediments in planted mangroves (Northern Viet Nam). Estuar. Coast. Shelf Sci.., 213, 28-39. doi:10.1016/j. ecss.2018.08.006.

Hofmann, D. J., Butler, J. H., and Tans, P. P. (2009). A new look at atmospheric carbon dioxide. Atmos. Environ., 43, 2084-2086. doi:10.1016/j.atmosenv.2008.12.028.

Kauffman, J. B., and Donato, D. C. (2012). Protocols for the measurenments, monitoring, and reporting of structure, biomass and carbon stock in mangrove forests. Bogor, Indonesia: Center for International Forestry Research (CIFOR), CIFOR Working Paper no. 86. (pp 40). doi:10.17528/cifor/003749.

Kristensen, E., and Andersen, F. Ø. (1987). Determination of organic carbon in marine sediments: Acomparison of two $\mathrm{CHN}$-analyzer methods. J. Exp. Mar. Biol. Ecol.., 109(1), 1523. doi:10.1016/0022-0981(87)90182-1.

Kristensen, E., Bouillon, S., Dittmar, T., and Marchand, C. (2008). Organic carbon dynamics in mangrove ecosystems: A review. Aquat. Bot., 89(2), 201-219. doi:10.1016/j. aquabot.2007.12.005.

Lovelock, C. E., Ruess, R. W., and Feller, I. C. (2011). $\mathrm{CO}_{2}$ Efflux from cleared mangrove peat. PLOS ONE., 6(6). doi:10.1371/journal. pone. 0021279 . 
Marchand, C., (2017). Soil carbon stocks and burial rates along a mangrove forest chronosequence (French Guiana). Forest Ecol. Manage., 384, 92-99. doi:10.1016/j. foreco.2016.10.030.

Meyers, A. P. (2003). Application of organic geochemistry to paleolimnological reconstruction: A summary of examples from the Laurentian Great Lakes. Org. Geochem., 34, 261-289. doi:10.1016/S01466380(02)00168-7.

McIntyre, A.D., and Holme, N.A. (1984). Methods for the study of marine benthos. London: Blackwell Scientific Publication, (pp. 387).

Mcleod, E., Chmura, G. L., Bouillon, S., Salm, R., Bjork, M., Duarte, C. M., Lovelock, C. E., Schlesinger, W. H., and Silliman, B. R. (2010). A blueprint for blue carbon: toward an improved understanding of the role of vegetated coastal habitats in sequestering $\mathrm{CO}_{2}$. Front. Ecol. Environ., 45, 67-73. doi:10.1890/ 110004.

Murdiyarso, D., Purbopuspito, J., Kauffman, J. B., Warren, M. W., Sasmito, S. D., Donato, D. C., Manuri, S., Krisnawati, H., Taberima, S., and Kurnianto, S. (2015). The potential of Indonesia mangrove forest of global climate change mitigation. Nat. Geosci., doi: 10.1038/ NCLIMATE2734.

Nehren, U., and Wicaksono, P. (2018). Mapping soil carbon stocks in an oceanic mangrove ecosystem in Karimunjawa Islands, Indonesia. Estuar. Coast. Shelf Sci., 214, 1185-193, doi:10.1016/j.ecss.2018.09.022.

Osland, M. J., Spivak, A. C., Nestlerode, J. A., Lessmann, J. M., Almario, A. E., Heitmuller, P. T., Russell, M. J., Krauss, K. W., Alvarez, F., Dantin, D. D., and Harvey, J. E., From, A. S., Cormier, N., and Stagg, C. L. (2012). Ecosystem development after mangrove wetland creation: Plant-soil change across a 20-year chronosequence. Ecosystems., 15, 848-866. doi:10.1007/s10021-012-9551-1.

Poeplau, C., Vos, C., and Don, A. (2017). Soil organic carbon stocks are systematically overestimated by misuse of the parameters bulk density and rock fragment content. SOIL., 3(1), 61-66. doi:10.5194/soil-3-61-2017.
Rahman, Hefni, E. H., and Rusmana, I. (2017). Stock estimation and carbon absorption of mangrove in Tallo River, Makassar. J. Forest Sci., 2, 19-28. doi:10.22146/jik.24867.

Ren, H., Chen, H., Li, Z., and Han, W. (2010). Biomass accumulation and carbon storage of four different aged Sonneratia apetala plantations in Southern China. Plant Soil., 327, 279-291. doi:10.1007/s11104-009-00537.

Retnowati, E. (1998). The contribution of Eucalyptus Grandis maiden plantation forest as rosot karbon in North Tapanuli. Bogor. Forest Research Bulletin. (pp. 611).

Rozainah, M. Z., Nazri, M. N., Sofawi, A. B., Hemati, Z., and Juliana, W. A. (2018). Estimation of carbon pool in soil, above and below ground vegetation at different types of mangrove forests in Peninsular Malaysia. Mar. Poll. Bull., 137, 237-245. doi:10.1016/j. marpolbul.2018.10.02.

Strickland, J. D. H and Parson, T. R. (1968). A practical handbook of seawater analysis. Fish. Res. Board Canada, Bull. (pp. 167-311).

Tue, N. T., Nguyen, T. N., Tran, D. Q., Hamaoka, H., Mai, T. N., and Omori, K. (2012). A cross system analysis of sedimentary organic carbon in the mangrove ecosystems of Xuan Thuy National Park, Vietnam. J. Sea Res., 67 (1), 69-76. 10.1016/j.seares.2011.10.006.

Twilley, R. R., Chen, R. H., and Hargis, T. (1992). Carbon sinks in mangroves and their implications to carbon budget of tropical coastal ecosystems. Water Air. Soil. Poll., 64(1-2), 265-288. doi:10.1007/bf00477106.

Wang, R., Tao, S., Wang, W., Liu, J., Shen, H., Shen, G., Wang, B., Liu, X., Li, W., and Huang, Y. (2012). Black carbon emissions in China from 1949 to 2050. Environ. Sci. Technol., 46, 7595-7603. doi:10.1021/es3003684.

Woodroffe, C. (1992). Mangrove sediments and geomorphology. Coast. Estuar. Studies, 7-41. doi:10.1029/ce041p0007.

Xue, B., Yan, C., Lu, H. and Bai, Y. (2009). Mangrove-derived organic carbon in sediment from Zhangjiang Estuary (China) mangrove wetland. J. Coastal Res., 25, 949-956. doi: 10.2112/08-1047.1. 